\title{
Hybridization of Green Energy Sources for the Electrification of Remote Villages: A Case Study at Adem Tuleman of Ethiopia
}

Wondwosen S Aga ( $\nabla$ wondwosenshiferaw7@gmail.com )

Haramaya Institute of Technology, Haramaya University

Ayele N. Legese

Haramaya Institute of Technology, Haramaya University

Abebe D Tolche

Haramaya Institute of Technology, Haramaya University

Negesh T Roba

Haramaya Institute of Technology, Haramaya University

\section{Research Article}

Keywords: hybrid energy system, optimization, photovoltaic, wind turbine, generator, HOMER

Posted Date: November 30th, 2021

DOI: https://doi.org/10.21203/rs.3.rs-1065267/v1

License: (9) This work is licensed under a Creative Commons Attribution 4.0 International License.

Read Full License 
Hybridization of green energy sources for the electrification of remote villages:

a case study at Adem Tuleman of Ethiopia

${ }^{*}$ Wondwosen S. Aga ${ }^{1,}$, Ayele N. Legese' ${ }^{2}$ Abebe D. Tolche ${ }^{3}$, and Negesh T Roba ${ }^{3}$

1 Department of Agricultural Engineering, Haramaya Institute of Technology, Haramaya University, Ethiopia, P.O. BOX 138 Dire Dawa, Ethiopia

2 School Electrical Engineering, Haramaya Institute of Technology, Haramaya University, Ethiopia, P.O. BOX 138 Dire Dawa, Ethiopia

3 School of Water Resources and Environmental Engineering, Haramaya Institute of Technology, Haramaya University, P.O. BOX 138 Dire Dawa, Ethiopia

*Corresponding author: Email: wondwosenshiferaw7@gmail.com

\section{ABSTRACT}

Background: Energy deeply influences the life of rural communities. The industrialized countries depend primarily on modern energy while the developing countries like Ethiopia heavily rely on traditional biomass. Thus, in Ethiopia, the energy sector faces dual challenges: one limited access to modern energy and the second is heavy reliance on traditional biomass energy sources to meet growing energy demand. The modern energy of the country is predominantly from hydropower which accounts for $90 \%$ and fuelwood accounts for more than $80 \%$ of households' energy supply today, this leads to deforestation and severe land degradation in the country.

Objective: This study aim at providing the way to diversify energy sources through integrated hybrid energy sources (wind, solar and diesel generator) to obtain a sustainable autonomous power supply system for remote site. 
Method: Standalone hybrid system configuration was design by using HOMER software and finds an optimal combination of clean energy as well as comparing it with other energy sources for Adem Tuleman one of the remote sites in Ethiopia. HOMER is optimization tool to determine the possible optimal architecture and control strategy of the system.

Results: The study found that the village had a $204.04 \mathrm{kWh} /$ day average energy demand with a $31 \mathrm{~kW} /$ day peak load, a $4.5 \mathrm{kWh} /$ day deferrable load, and $0.9 \mathrm{kWh} /$ day peak deferrable load. Simulation results demonstrated that the proposed system was a feasible solution to electrify Adem Tuleman. A financial analysis indicated that the project would have an initial capital cost of $\$ 24,817.00$, an operating and maintenance cost of $\$ 12,862.00$, and a total net present value of $\$ 189,233.00$. The minimum cost of energy obtained was $\$ 0.195 / \mathrm{kWh}$.

Conclusion: The simulation result indicates that the proposed standalone hybrid system would be a climate smart and feasible solution for electrify remote village. Moreover, hybrid energy systems allow the effective way of utilizing available renewable energy in the village and providing clean energy which can alleviate energy poverty in many remote sites of Ethiopia.

Keywords: - hybrid energy system, optimization, photovoltaic, wind turbine, generator, HOMER

\section{Introduction}

Energy deeply influences the life of rural communities. It is fundamental to all aspects of human welfare, including access to clean water, health care and education, and increasing agricultural productivity(Tessama et al., 2013). Globally, an energy demand is growing and is expected to continue to grow in the coming decades with the projected growth of the population and with the expansion of energy-dissipative economic activities. The industrialized countries depend primarily on modern energy while the developing countries 
heavily rely on traditional biomass (Tajebe, 2016). Likewise, About 2.7 billion people lack access to efficient and clean energy for cooking and heating and 1.3 billion lack access to electricity; about $84 \%$ of this deprived population lives in rural areas of sub-saharan Africa or Southeast Asia (Tessama et al., 2013) and (Kang, 2020). Access to modern energy supports both income generation activities and the national development agenda through improving education, reducing indoor air pollution, and ensuring environmental sustainability (Mondal et al., 2018a).

In Ethiopia, the energy sector faces dual challenges: one limited access to modern energy and the second is heavy reliance on traditional biomass energy sources to meet growing energy demand(Mondal et al., 2018b). The modern energy of the country is predominantly from hydropower which accounts for $90 \%$ and fuelwood accounts for more than $80 \%$ of households' energy supply today, this leads to deforestation and severe land degradation in Ethiopia (Girma, 2016) and (Dingeto Hailu and Kalbessa Kumsa, 2021). For instant, the energy mix of Sub-Saharan African countries including Ethiopia is dominated by traditional biomass fuels. Biomass fuel constitutes about $90 \%-98 \%$ of the total residential fuel consumption in most of sub-Saharan countries, and Ethiopia ranks second, next to Nigeria in terms of biomass fuel consumption(Negash et al., 2017). Such excessive reliance on biomass fuels and inefficient combustion technologies have resulted in adverse consequences including land degradation, deforestation, increased emissions of greenhouse gases, desertification, loss of biodiversity and health problem(Bekere and Megerssa, 2020). Meanwhile, In Ethiopia heavy reliance on hydropower, climate change and variability are key concerns for the reliability and consistency of hydroelectric power generation and supply. Thus, over-reliance on one source of power is not optimal for Ethiopia's energy security(World Bank, 2017). The government of Ethiopia with the collaboration of the Chinese government prepared a solar and wind master plan for the whole country, which can 
be very useful to identify the gross amount and distribution condition of wind and solar energy resources, construction conditions, cost, and other limiting factors of wind and solar power generation projects (Derbew, 2013). Based on the analysis of this master plan, Ethiopia has a capacity of 1,350 GW of energy from wind and has an annual total solar energy reserve of 2.199 million TWh/annum (Derbew, 2013).

Although grid extension remains the preferred mode of electrification, it faces several challenges in many countries. First, the generating capacity is inadequate in many countries and even the urban areas remain poorly supplied which is characterized by frequent interruption especially during the dry season. Even if the grid is extended, rural consumers are unlikely to receive a reliable and high-quality supply at the current prices for grid electricity. Second, grid extension is capital-intensive, and depending on the geographical location and remoteness, the cost can vary between $\$ 6,700$ and $\$ 19,000 / \mathrm{km}$ (Boait, 2014). Third, for countries with a low level of electrification, the priority will be to connect the urban areas and peri-urban areas first, thereby neglecting the rural needs.

Nowadays, In Ethiopia policy also gave due attention to rural electrification by using renewable energy-based through off-grid technology, which will more economical than installing a gridline because some of the rural areas are geographically not suitable for grid (Dingeto Hailu and Kalbessa Kumsa, 2021). A hybrid system is considered as one of the most efficient means to access electricity from locally available renewable energy resources where access to the national grid is quite impossible and also not economic. Hybrid Energy Systems (HES) generally integrate renewable energy sources with fossil fuel-powered diesel/petrol generators to provide electric power where the electricity is either fed directly into the grid or to batteries for energy storage. The role of integrating renewable energy in a hybrid energy system is primarily to save diesel fuel (Ani, 2016, Bhandari et al., 2015) and (Chang and Lin, 2015). 
Therefore, in different remote cite like Adem Tuleman kebele, off-grid energy supply from renewable energy mainly solar and wind are one alternative ways of securing energy demand and ensure sustainable renewable energy utilization. Currently, the main energy source in at the site is biomass for cooking household and fossil fuel for lighting these lead to deforestation, land degradation and incur a lot of cost to purchase conventional fuels. The kebele is among remote area in Ethiopia lacking access to the grid electric energy services and the study focus to show the potential renewable energy resources available in the kebele and current energy trends of the village as well as possible mechanism of utilizing locally available renewable energy. So far, a few researches were conducted in Ethiopia especially remote village like Adem Tuleman to solve problem of access to modern energy and empower the development of alternative energy technology. Therefore, this article presents the case study on renewable energy potential in Adem Tuleman kebele with current state in a more comprehensive way and provides valuable information for researchers, industrial companies and decision makers to promote investment in renewable energy technology development. The case study also cover assessment of energy demands of the village through interviews and focus group discussion, and shows the possible approach of harnessing available renewable energy at Adem Tuleman to secure energy demands of the village. The paper also examines and recommends possible optimal combination of a hybrid system for the village by using Hybrid Optimization of Multiple Energy Resources (HOMER) and which will be extended to a different remote village in the country.

\section{Methodology}

\subsection{Site Description}

Adem Tuleman kebele is among remote areas in the southeast part of Ethiopia located at $7^{\circ} 42.38^{\prime} \mathrm{N}$ to $7^{\circ} 46.32^{\prime} \mathrm{N}$ and $39^{\circ} 45.33^{\prime} \mathrm{E}$ to $39^{\circ} 51.20^{\prime} \mathrm{E}$ in Oromia Region, Arsi Zone, Robe Woreda (Figure. 1). The village has about one hundred fifty householders with five average 
family members, two primary schools, small health centers, and religious institutes (church, mosque). The community in the village lacks access to grid line electricity and suffers land degradation due to deforestation to meet their daily energy demand. According to the National Aeronautics and Space Administration (NASA) data, the village has a $3.86 \mathrm{~m} / \mathrm{s}$ average annual wind speed and $5.78 \mathrm{kWh} / \mathrm{m}^{2} /$ day average annual solar radiation.

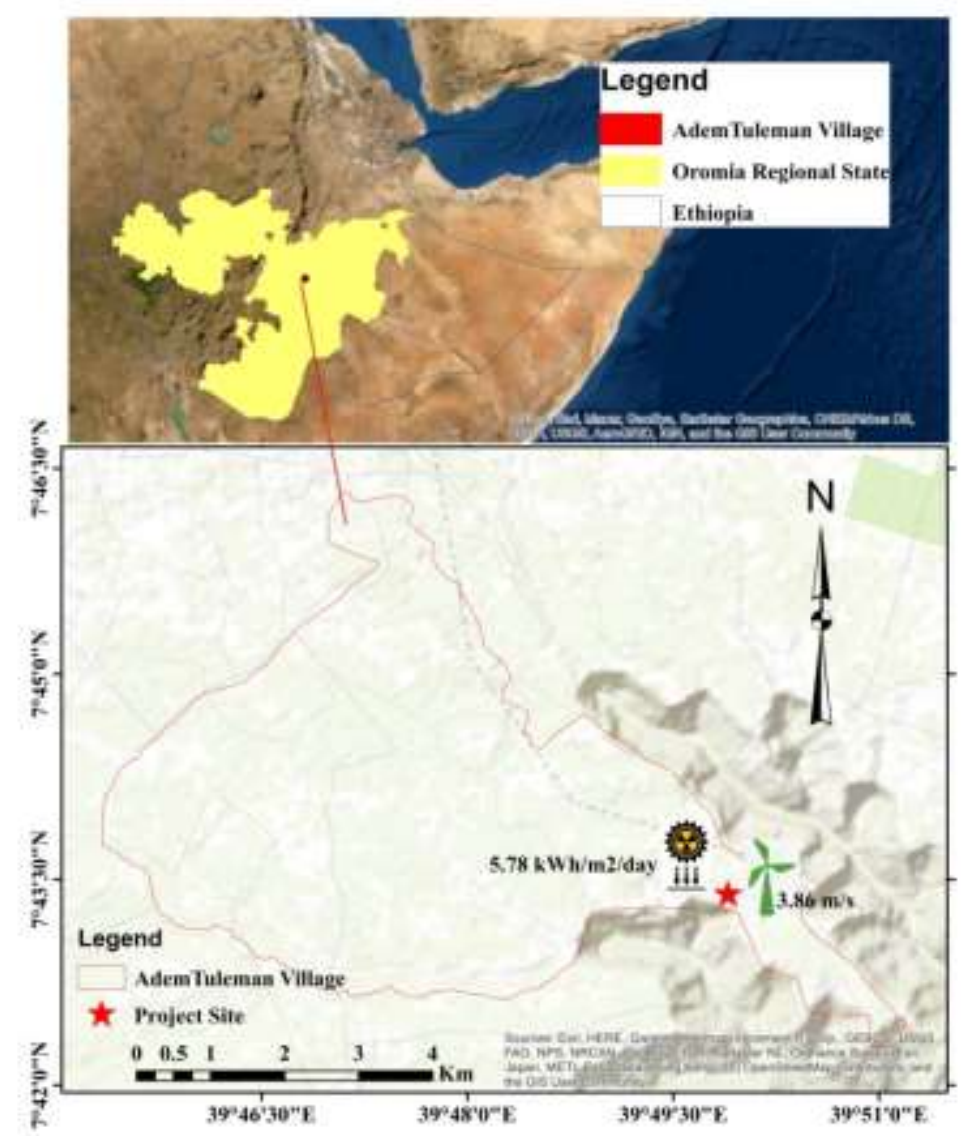

Figure 1 Maps' of Adem Tuleman

\subsection{Data Collection}

To design and simulate a hybrid energy system for Adem Tuleman kebele the data were collected (Table 1) and evaluated using HOMER. 
Table 1. Data collected during this study

\begin{tabular}{ll}
\hline Data & Source \\
\hline The average daily energy demand of the site & $\begin{array}{l}\text { (Woldeamanuel, 2017),(Girma, } \\
\text { 2013) and (I.O, Adewumi and }\end{array}$ \\
& $\begin{array}{l}\text { B.A, 2015) } \\
\text { (Muda and Fong, 2014) }\end{array}$ \\
$\begin{array}{l}\text { Average Annual wind energy resource input at 50m } \\
\text { Average Annual solar energy resource input on the } \\
\text { horizontal surface }\end{array}$ & (Muda and Fong, 2014) \\
Solar pump specification & (Pumps, 2000) \\
\hline
\end{tabular}

To determine the required capacity of the stand-alone power system, estimating the peak-load demand is the first step in process of system design. The project is formulated to study the design feasibility of a standalone hybrid (solar PV, Wind, and diesel generator) energy generation system. The hybrid standalone systems have been providing primary energy for devices like radio, TV, refrigerator, different size of the light bulb, amplifier, and speaker at sites far away from a conventional power system. The average daily power requires for Adem Tuleman village was $204.045 \mathrm{kWh}$ in which 150 households, schools, administrative offices, health centers, shopping centers, and religious institutes use for different purposes. Hybrid system sizing starts with compiling a list of all loads that are to be served. Not all loads are constant or are connected at all times. Therefore, all loads are expressed in terms of the peak watts they consume and the duty ratio. The peak power consumption is used in determining the size of PV, Wind turbine and Generator, and the wire connecting to the source. The duty ratio is used in determining the contribution of an individual load in the total energy demand.

\subsection{Electric load of the Village}

From the survey data, Adem Tuleman is among remote villages in Ethiopia, and the electrical load demand is very low dominated by lighting load. In this study, 150 rural households with an average family size of five, health extension clinic, kebele administration office, religion (mosque and church), and commercial centers are considered. The community in the villages are categorized into three categories based on their income as shown in Table 2;- higher class, 
medium class, and lower class (Girma, 2013) and (I.O, Adewumi and B.A, 2015) and also the overload profile of the village is shown in (Figure $2 \mathrm{a}$, and b ). In addition to the lighting load, the village required domestic water for different purposes such as drinking, washing, preparing food, and livestock.

Table 2. Load Profile of the village

\begin{tabular}{|c|c|c|c|c|c|c|}
\hline \multicolumn{7}{|c|}{ Adem Tuleman Load profile } \\
\hline $\begin{array}{l}\text { Categories } \\
\text { household }\end{array}$ & $\begin{array}{l}\text { Number of } \\
\text { Households }\end{array}$ & Appliance type & Rating (W) & $\begin{array}{l}\text { Number of } \\
\text { Appliances }\end{array}$ & $\begin{array}{l}\text { Running } \\
\text { time (hr) }\end{array}$ & $\mathrm{kWh}$ \\
\hline $\begin{array}{l}\text { Higher } \\
\text { class }\end{array}$ & 10 & $\begin{array}{l}\text { CFL lamp } \\
\text { Tape recorder } \\
\text { Television } \\
\text { Charging mobile }\end{array}$ & $\begin{array}{l}15 \\
50 \\
250 \\
5 \\
\text { Total kWh/ }\end{array}$ & $\begin{array}{l}4 \\
1 \\
2 \\
25 \\
\text { ay /high-class }\end{array}$ & $\begin{array}{l}6 \\
10 \\
4 \\
3 \\
\text { household }\end{array}$ & $\begin{array}{l}3.60 \\
5.00 \\
20.00 \\
3.75 \\
32.35\end{array}$ \\
\hline $\begin{array}{l}\text { Middle } \\
\text { class }\end{array}$ & 45 & $\begin{array}{l}\text { CFL lamp } \\
\text { Tape recorder } \\
\text { Charging mobile }\end{array}$ & $\begin{array}{l}15 \\
50 \\
5 \\
\end{array}$ & $\begin{array}{l}4 \\
1 \\
15 \\
\text { middle-class }\end{array}$ & $\begin{array}{l}6 \\
10 \\
3 \\
\text { household }\end{array}$ & $\begin{array}{l}16.20 \\
22.50 \\
3.375 \\
42.075\end{array}$ \\
\hline lower class & 95 & $\begin{array}{l}\text { CFL Lamp } \\
\text { Tape Recorder }\end{array}$ & $\begin{array}{l}15 \\
50 \\
\end{array}$ & $\begin{array}{l}2 \\
1 \\
\mathrm{kWh} / \text { day of }\end{array}$ & $\begin{array}{l}6 \\
8 \\
\text { ower class }\end{array}$ & $\begin{array}{l}42.0 / 5 \\
5.70 \\
71.25 \\
76.95\end{array}$ \\
\hline The public an & ad commercial cent & & & & & \\
\hline School & 1 & $\begin{array}{l}\text { CFL lamp } \\
\text { Desktop } \\
\text { Computer } \\
\text { Microphone } \\
\text { Television } \\
\text { Tape Recorder } \\
\text { Printer } \\
\text { Copy Machine }\end{array}$ & $\begin{array}{l}15 \\
100 \\
75 \\
250 \\
50 \\
40 \\
100\end{array}$ & $\begin{array}{l}1 \\
1 \\
4 \\
2 \\
1\end{array}$ & $\begin{array}{l}3 \\
3 \\
8 \\
8 \\
8 \\
\end{array}$ & $\begin{array}{l}1.8 \\
8.00 \\
0.225 \\
0.75 \\
1.60 \\
0.64 \\
0.80\end{array}$ \\
\hline Health center & 1 & $\begin{array}{l}\text { Refrigerator } \\
\text { Television } \\
\text { CFL lamp } \\
\text { Lab. Equipment } \\
\text { Others }\end{array}$ & $\begin{array}{l}200 \\
250 \\
15 \\
1000 \\
150 \\
\end{array}$ & $\begin{array}{l}\text { Total kWh/da } \\
1 \\
1 \\
8 \\
1 \\
1 \\
\end{array}$ & $\begin{array}{l}\text { of school } \\
24 \\
14 \\
12 \\
12 \\
6\end{array}$ & $\begin{array}{l}13.815 \\
4.8 \\
3.50 \\
1.44 \\
12.00 \\
0.90 \\
\end{array}$ \\
\hline $\begin{array}{l}\text { Commercial } \\
\text { center }\end{array}$ & 1 & $\begin{array}{l}\text { CFL Lamp } \\
\text { Tape Recorder } \\
\text { Refrigerator }\end{array}$ & $\begin{array}{l}15 \\
50 \\
200 \\
\end{array}$ & $\begin{array}{l}\text { Wh/day of } \mathrm{H} \\
6 \\
2 \\
1 \\
\end{array}$ & $\begin{array}{l}\text { alth center } \\
12 \\
12 \\
12 \\
\end{array}$ & $\begin{array}{l}22.64 \\
1.08 \\
1.20 \\
2.40 \\
\end{array}$ \\
\hline $\begin{array}{l}\text { Adem } \\
\text { Tuleman } \\
\text { Kebele } \\
\text { administrative }\end{array}$ & $\begin{array}{l}\text { Judiciary/Com } \\
\text { munity }\end{array}$ & $\begin{array}{l}\text { Desktop } \\
\text { Printer } \\
\text { Desktop } \\
\text { Wireless } \\
\text { Telephone } \\
\text { CFL }\end{array}$ & $\begin{array}{r}\text { otal kWh/day } \\
100 \\
40 \\
100 \\
2\end{array}$ & $\begin{array}{r}\text { of the comme } \\
1 \\
1 \\
1 \\
1\end{array}$ & $\begin{array}{r}\text { cial center } \\
8 \\
8 \\
8 \\
8\end{array}$ & $\begin{array}{l}4.68 \\
0.8 \\
0.32 \\
0.8 \\
0.16\end{array}$ \\
\hline
\end{tabular}




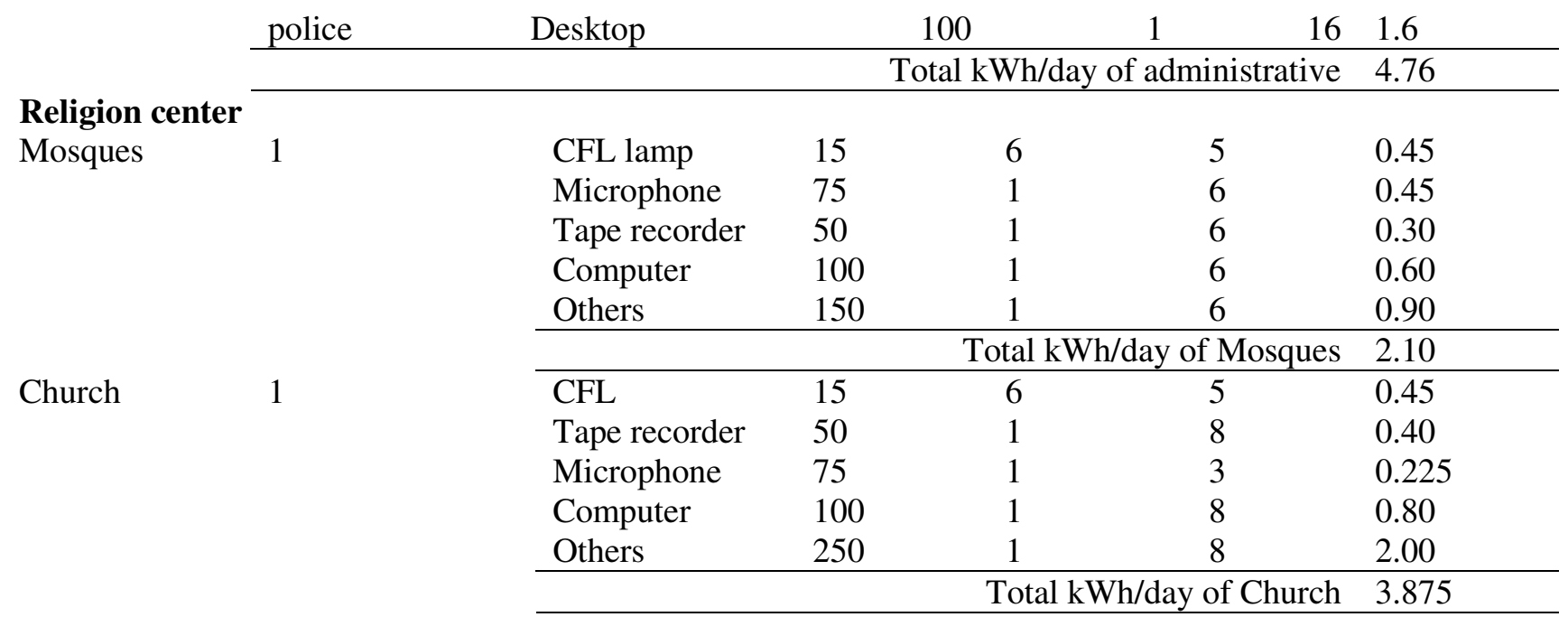

In addition to a hybrid energy system, the community in the village is expected to use energy-saving cook stove for cooking the daily livelihood of the household

Total average daily energy Demand of Adem Tuleman 204.045

Source:(Woldeamanuel, 2017)(Girma, 2013) and Adewumi and B.A, 2015)

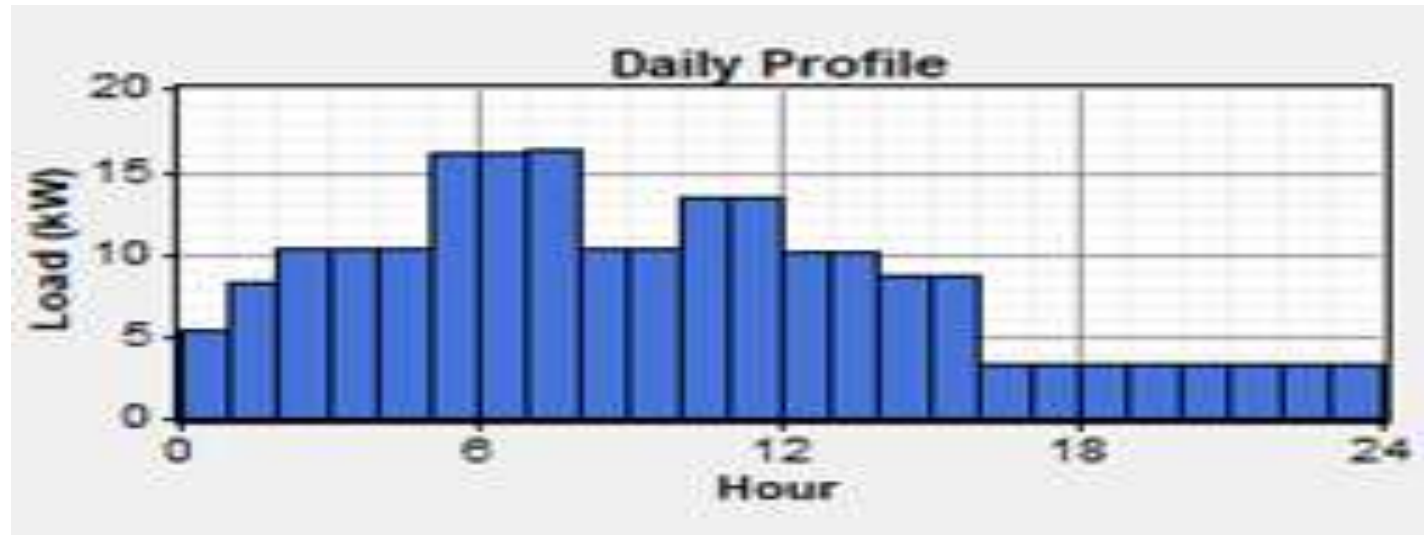

a)

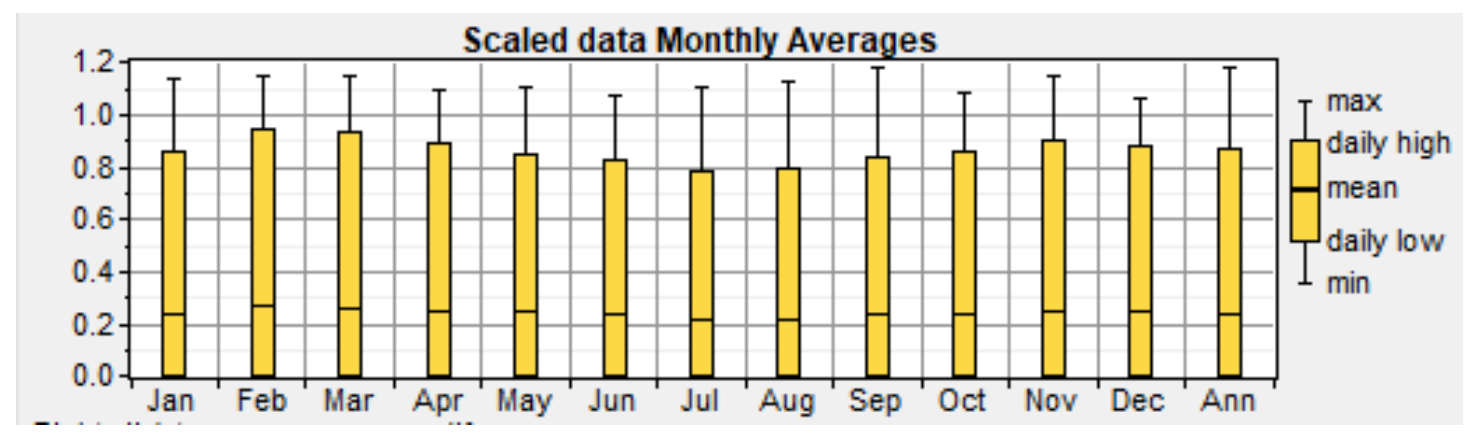

b)

Figure 2 Primary load profile of Adem Tuleman

Depending on households and what sort of livelihoods they are involved in; communities also use water for watering vegetables around their house, preparing food for sale, or other small 
businesses. There is increasing recognition that rural water services should be designed with some of these additional needs in mind, intending to maximize the benefit that rural people gain from access to reliable water service besides rural electrification. Based on abovementioned water demand, five water pumps are sufficient to deliver the water needs of the village. Whereas one pump for school, health center, and kebele administrative, one for the church, one for the mosque, and the remaining two for communities. The selected water pump has a capacity of $900 \mathrm{~W}$ power rating, with a pumping capacity of 1301 iter/min. The specification of the solar pump is described in Table 3.

Table 3. Solar water Pump specification

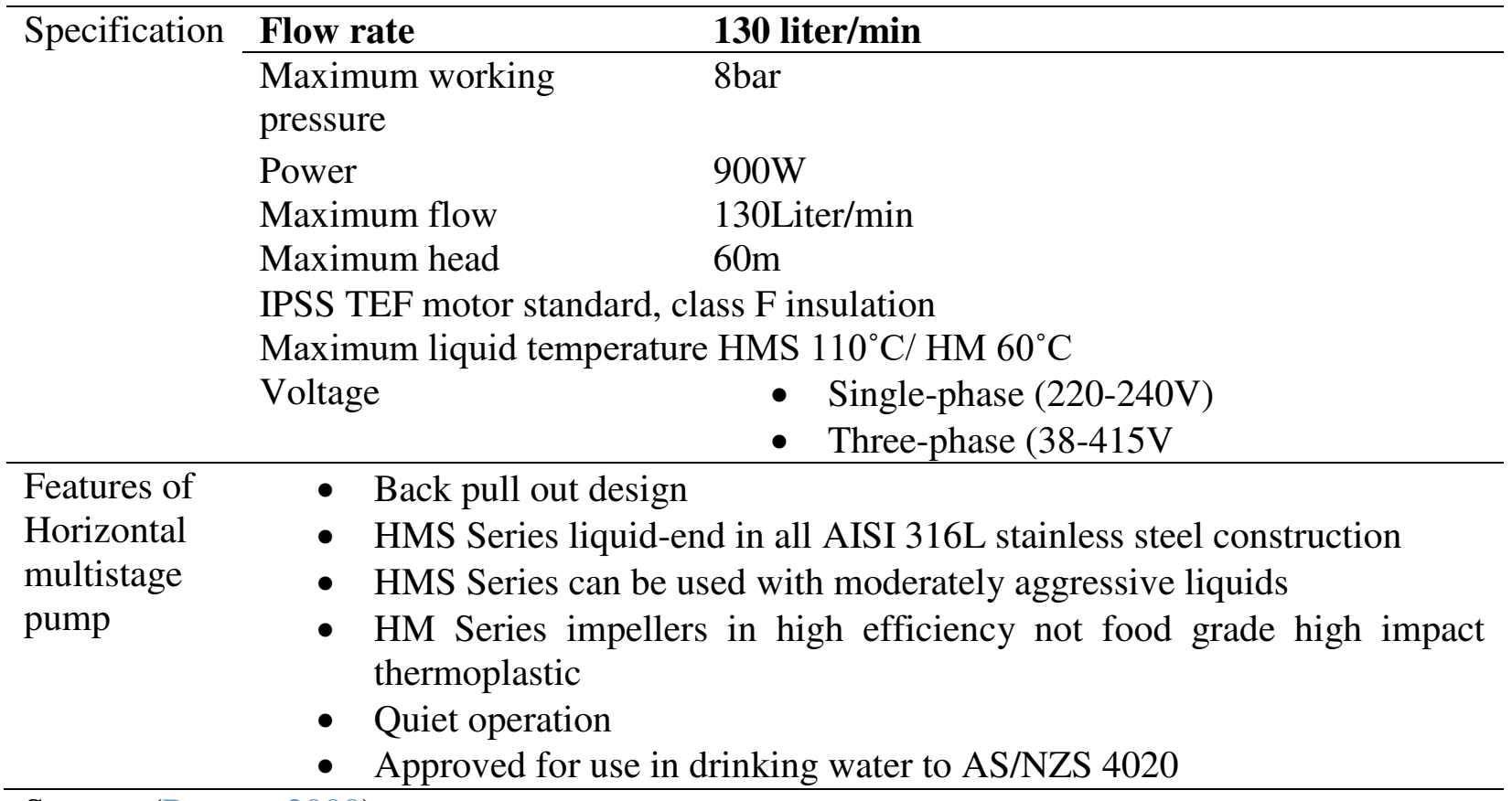

Source: (Pumps, 2000)

The required amount of water needed per family is approximately 100liter/day and 100litter/day for each public and religious area. This assumption is based on the country average consumption of water per person and per cattle, i.e. the average consumption is 20liter/person/day (Sharma and Bereket, 2008), and cattle in climates with temperatures around $20^{\circ} \mathrm{C}$ can be expected to have an average demand for drinking water in the order of 
40L/cattle/day (Davis and Watts, no date). Since the village has 150 households with an average of five-member per family, public sector (health, school, hoping center, and administration) as well for Church and Mosque, the total water consumption of Adem Tuleman per day is around $75.5 \mathrm{~m}^{3} /$ day without including livestock in the village because one river is available in the village which serves as drinking water for cattle's. Five water pumps with a capacity of 130 liter/min can provide more than $88 \mathrm{~m}^{3} /$ day if it runs for only two hours per day. A water tank of capacity 90 -meter cube is considered and at full load, the pumps draw $4.5 \mathrm{~kW}$ of electrical power and pump $39 \mathrm{~m}^{3}$ per hour. The peak deferrable load is $0.9 \mathrm{~kW}$, which is the rated power of the pump. It would take 2 hours for the pumps at full power to fill the storage tank. So, the storage capacity is 2 hours times $4.5 \mathrm{~kW}$, which is $9 \mathrm{kWh}$. It would take the pumps 1 hour and 56 minutes at full power to meet the daily requirement of water for the village. So, the average deferrable load is two hours per day times $4.5 \mathrm{~kW}$, which is $9 \mathrm{kWh} /$ day. When we say deferrable load in hybrid system design, it means the load is an electrical load that requires a certain amount of energy within a given period, but the exact timing is not important, it can wait until power is available (Vázquez et al., 2012). Loads are normally classified as deferrable when they are associated with storage. In this case, the water pump is linked with the storage tank as result it is considered a deferrable load of the village and its profile is illustrated in Figure 3.

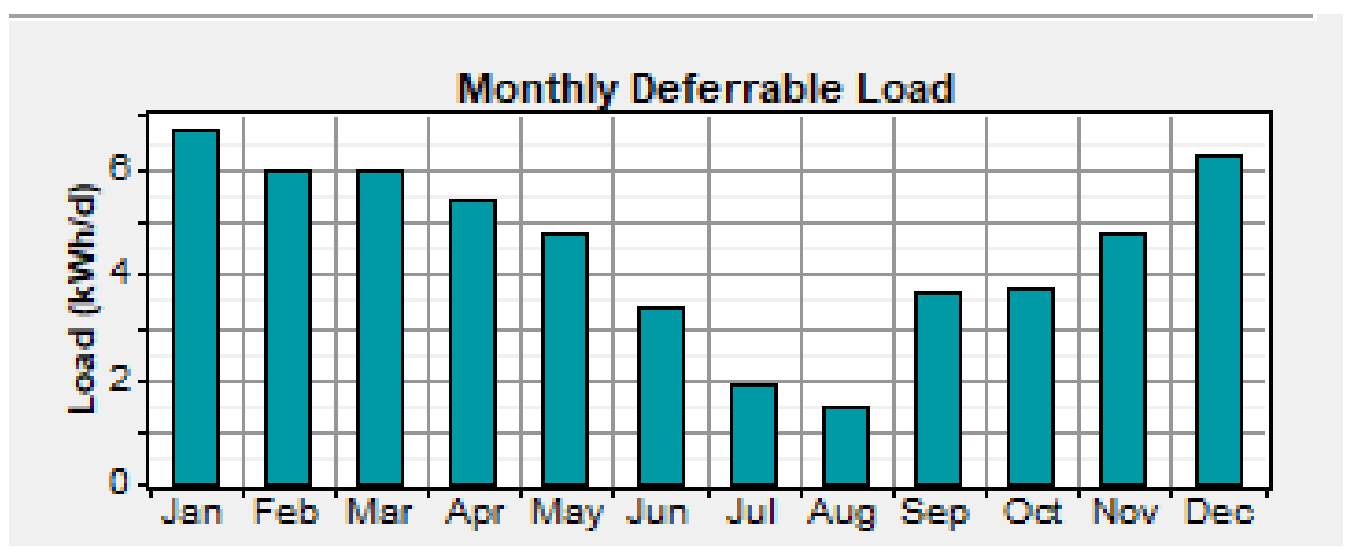

Figure 3 Deferrable load profiles 
HOMER evaluates various combinations for the given input and then gives the optimized output. This will help to compare the various results obtained during the simulation. This allows us to select the feasible hybrid system design in terms of cost, space availability, and reliable energy supply for the remote village. HOMER software needs hourly load as input for simulation. To get the hourly load of the village the above loads are distributed in the EXCEL spreadsheet program from the knowledge of load usage time, which is gained from the electrified village of the same socio-economic condition. For instance, lighting loads are switched on from 18:00-23:00, microphones are operated during daytime in school and also nighttime in the religious center and the entertainment devices are usually switched on when required.

\subsection{Solar and Wind Data Resources}

Estimating the energy requirement or load profile and assessing the realistic solar resource and wind resource availability are the most important tasks in hybrid energy system design. This is very important from the sizing point of view because it tells about the amount of energy harvested by the solar PV panel and wind turbine.

\subsection{Solar Radiation Data}

PV energy is abundantly available in the environment and it is free from pollution. The nature of the PV system output power depends on the geographical location (Mohanty et al., 2015). The PV system is a possible renewable energy source, which utilizes to overcome the dependency on fossil fuel (Sawle et al., 2018). Using the latitude and longitude of the selected site the solar radiation data were obtained from the National Aeronautics and Space Administrative (NASA) (Muda and Fong, 2014). The optimal monthly average solar global horizontal irradiance (GHI) data were collected using the Homer resources tool at $7^{\circ} 43.4^{\prime} \mathrm{N}$, $39^{\circ} 49.9^{\prime} \mathrm{E}$ in Adem Tuleman village, Ethiopia. The collected data was used to estimate the 
performance of various components used in the designed hybrid Power system to fulfill the load requirements for the village.

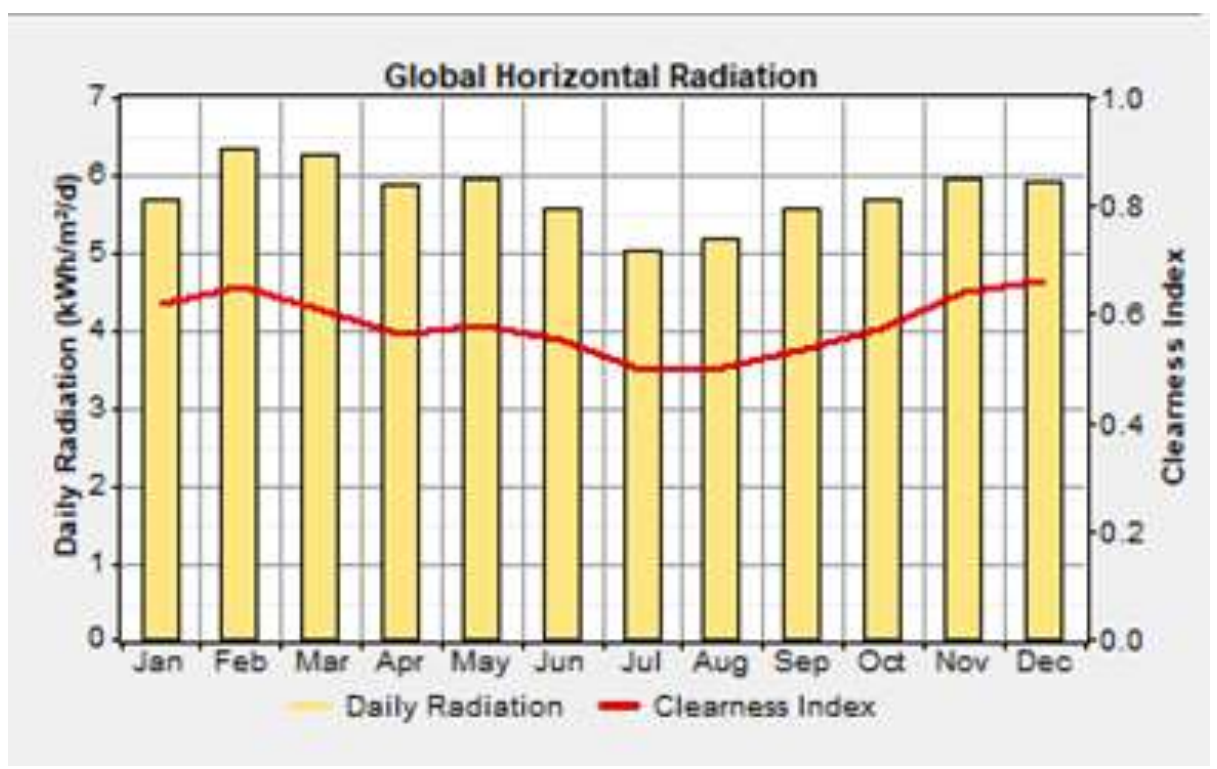

Figure 4 Average Monthly Global radiations on a horizontal surface

As shown in Figure 4 and Table 4 the average solar radiation ranges from $5.03 \mathrm{kWh} / \mathrm{m}^{2} /$ day to $6.36 \mathrm{kWh} / \mathrm{m}^{2}$. This data is used to determine the size of the solar panel and help to design an optimal and reliable hybrid energy system that can secure the energy demands of the village. The relatively high values of radiation were achieved in February, March, May and November and the small in July and August as shown on Figure 4. The clearness index can be achieved from solar radiation data by considering it in HOMER software. According to the data, the clearness index is high in December, January and February.

Table 4 Monthly average wind speed and solar global horizontal irradiance (GHI) data

\begin{tabular}{lllllllllllll}
\hline Months & Jan & Feb & Mar & Apr & May & Jun & July & Aug & Sep & Oct & Nov & Dec \\
\hline $\begin{array}{l}\text { Clearness } \\
\text { index }\end{array}$ & 0.651 & 0.650 & 0.605 & 0.562 & 0.581 & 0.552 & 0.496 & 0.502 & 0.53 & 0.577 & 0.642 & 0.662 \\
$\begin{array}{l}\text { Daily radiation } \\
\text { (kWh/m } \mathbf{2} / \mathbf{d a y}\end{array}$ & 5.67 & 6.36 & 6.25 & 5.88 & 5.96 & 5.56 & 5.03 & 5.19 & 5.55 & 5.69 & 5.94 & 5.920 \\
$\begin{array}{l}\text { Wind speed } \\
\text { (m/s) }\end{array}$ & 4.49 & 4.09 & 3.88 & 3.90 & 3.80 & 3.84 & 3.44 & 3.23 & 3.24 & 3.67 & 4.22 & 4.43 \\
\hline
\end{tabular}

Source:(Muda and Fong, 2014) 


\subsection{Wind Speed Data}

Wind Energy is also freely available in the environment, a pollution-free source of energy whose performance of the output power generation depends on the wind potential of the design location (Mazzoni and Isaac, 2003). The same as solar radiation data, wind speed data is also essential for hybrid system analysis. Wind speed data were obtained from the NASA database for the location of Adem Tuleman, Ethiopia (Muda and Fong, 2014). Wind speed at $50 \mathrm{~m}$ above the surface of the earth for terrain similar to airports, the monthly average over the 10 years was used as shown in Figure 5 and Table 4. From Table 4, the maximum value of wind speed is achieved in December and January. The value ranges in between $3.23 \mathrm{~m} / \mathrm{s}-$ $4.49 \mathrm{~m} / \mathrm{s}$. The number implies that the wind potential of Adem Tuleman is sufficient to drive the wind turbine to generate electricity or pump water for the village.

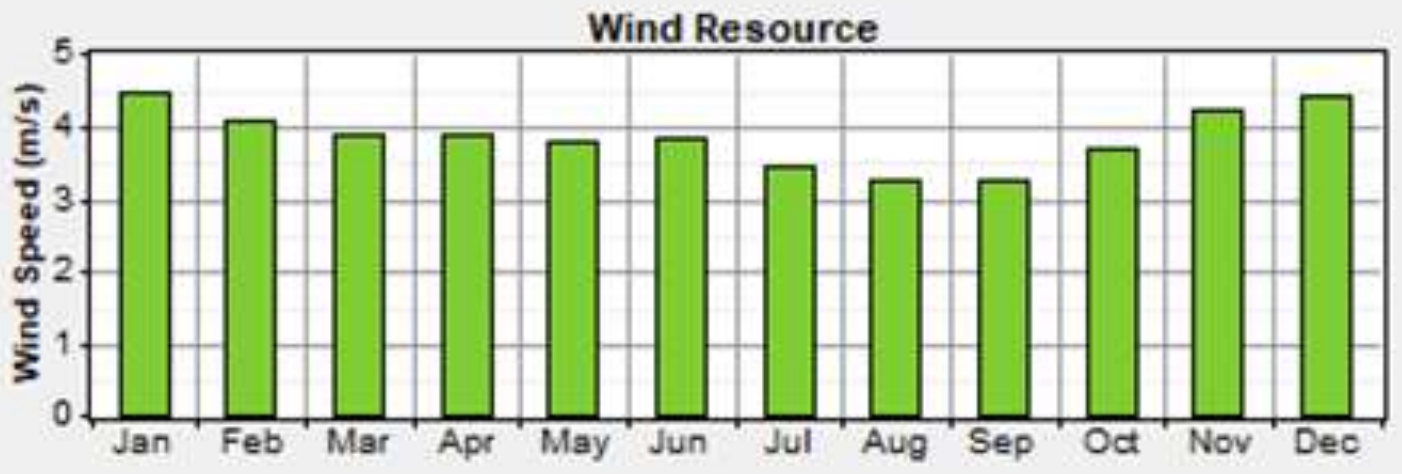

Figure 5 Average monthly wind speed of the study area

\subsection{Hybrid System Components and its Configuration}

The term hybrid energy system refers to those applications in which multiple energy conversion devices are used together to supply an energy requirement. These systems are often used in isolated applications and normally include at least one renewable energy source in the configuration. Hybrid energy systems are used as an alternative to conventional systems, which typically are based on a single fossil fuel source. Hybrid energy systems may 
also be used as part of distributed generation applications in conventional electricity grids (Sawle et al., 2018; Ani, 2016; Ashok, 2007) and (Martínez and Mart, 2017). A hybrid solarwind-diesel power generation system coupled to a battery bank consists of a PV module, a wind turbine, a diesel generator, a solar regulator, a battery bank, and an inverter. A schematic diagram of the proposed hybrid system is shown in Fig. 6. The PV module and the wind turbine work together to meet the load demand.

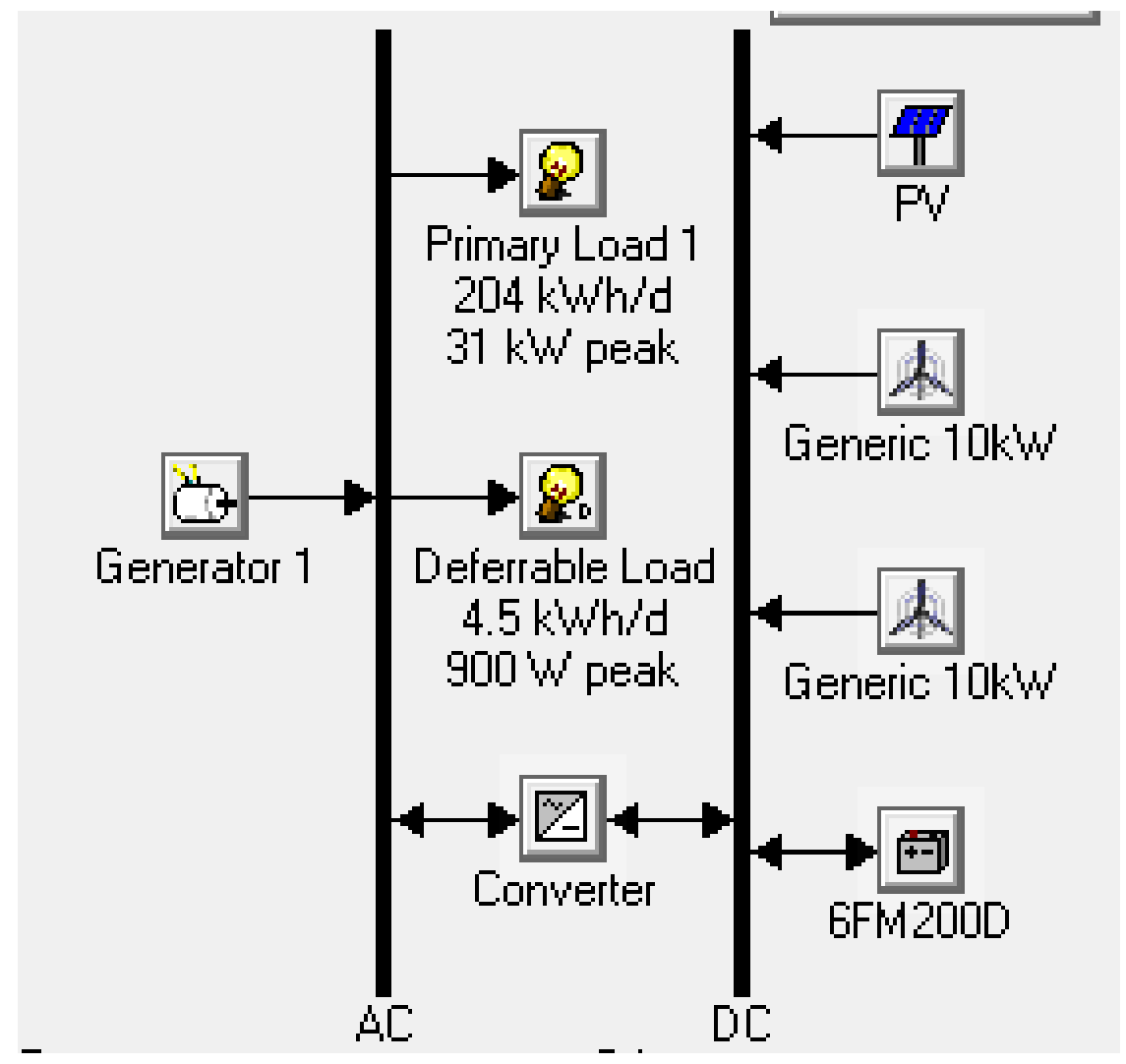

Figure 6 Hybrid system configurations

When the renewable energy sources are sufficient, the generated power, after meeting the load demands of the village, provides energy to the battery bank up to its full charge. The battery supplies energy demand help the system to cover the load requirements when the system covers the load requirements at time energy from renewable energy is inferior to the load demand. The load will be supplied by diesel generators when both wind turbine and PV 
array are insufficient and the storage is depleted. The overall hybrid system design and optimization of this study is summarized in Fig. 7.

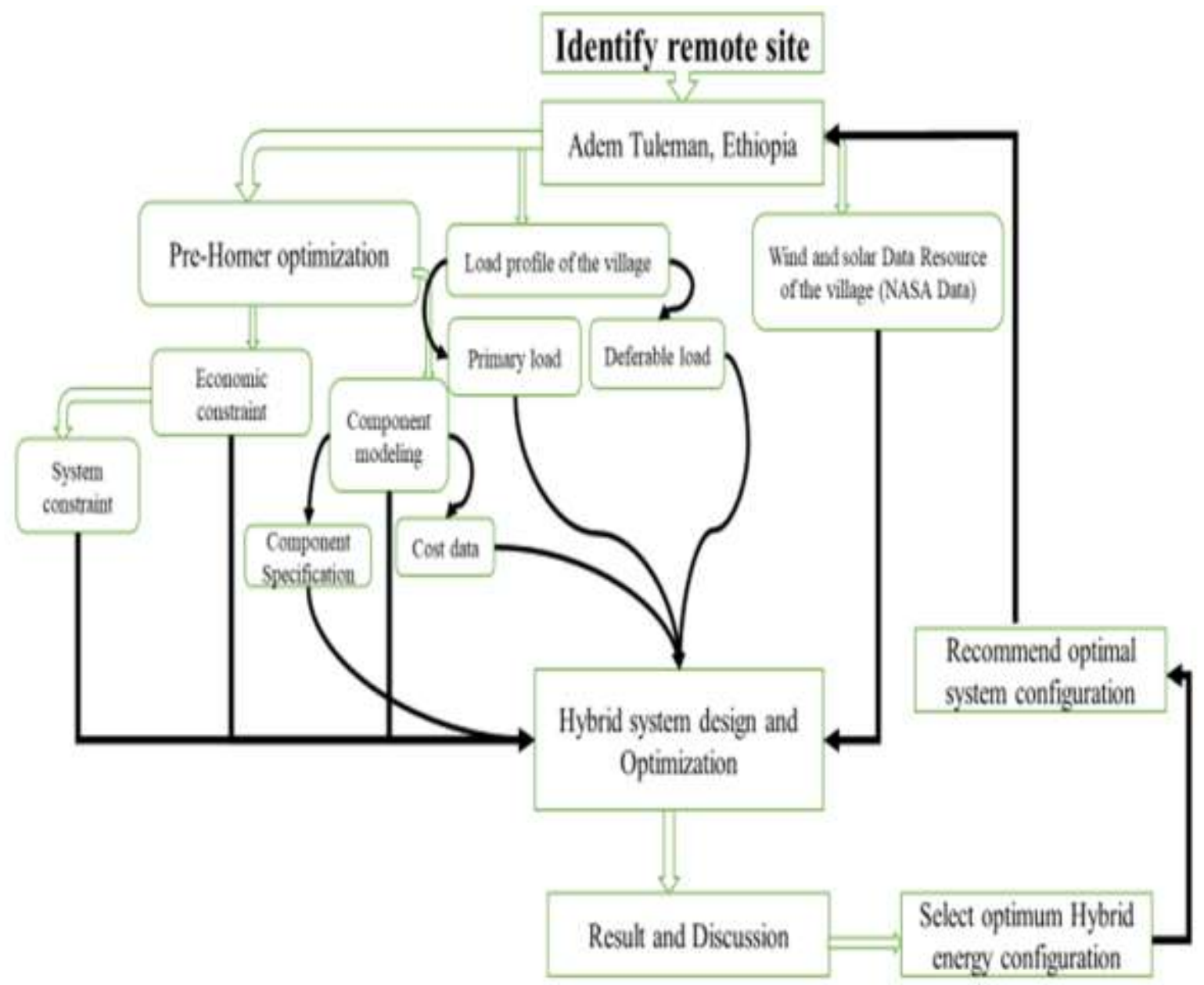

Figure 7. Schematic diagram describing hybrid system design and optimization approach

\subsubsection{Solar Photovoltaic (PV)}

A solar photovoltaic (PV) is one of the components in the Adem Tuleman hybrid standalone power system. PV technology has the versatility and flexibility for developing standalone electricity systems for different regions, especially in remote rural areas. The PV output power depends on geographical locations and timing (Mohanty et a., 2016). So, it is very important to select a proper site based on the solar resources of the village. To eliminate module shading by relocating the mounting system which does not cost any additional money and can increase the system's efficiency by a large percentage. In general, to optimize the 
system (i) the system was correctly sited out of the shade, (ii) the orientation of the PV panel was optimized to maximizing annual PV output based on local meteorological conditions, (iii) mounting options that could maximize insolation gain was considered and (iv) modules were selected according to a system's parameter. Using the solar radiation available, the hourly energy output of the PV generator $\left(E_{\mathrm{PVG}}\right)$ can be calculated according to the following equation (Ani, 2016);-

$$
E_{P V G}=G(t) * A * P * \eta_{P V G} \ldots \ldots \ldots \ldots \ldots \ldots \ldots 1
$$

An assumption was made that the temperature effects (on PV cells) will be ignored.

Where:

$\mathrm{G}(\mathrm{t})$ is the hourly irradiance in $\mathrm{kWh} / \mathrm{m}^{2}, \mathrm{~A}$ is the surface area in $\mathrm{m}^{2}, \mathrm{P}$ is the PV penetration level factor and $\eta$ is the efficiency of PV generator PVG

A low maintenance cost was considered for the PV system because little or no maintenance is needed for the panels and a derating factor of $80 \%$ and 25 -years lifetime.

\subsubsection{Wind turbine}

Wind turbines work by converting the kinetic energy in the wind, first to rotational kinetic energy in the turbine, and then electrical energy that can be supplied to the village (Mazzoni and Isaac, 2003). The energy available for conversion mainly depends on the average wind speed and swept area of the turbine (Ahmed et al., 2009; Udayakanthi, 2015). The fundamental equation governing the mechanical power capture of the WT rotor blades, which drives the electrical generator, is given by;

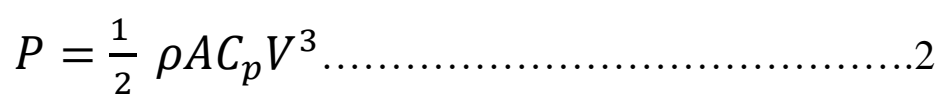

Where $\rho$ is the air density $\left(\mathrm{kg} / \mathrm{m}^{3}\right), \mathrm{A}$ is the area swept by the rotor blades, $\mathrm{V}$ is the velocity of air $(\mathrm{m} / \mathrm{sec})$, and $\mathrm{Cp}$ is the power coefficient of the wind turbine. 
The theoretical maximum value of power coefficient $\mathrm{Cp}$ is 0.59 , and it is often expressed as a function of the rotor tip-speed to a wind-speed ratio (TSR). TSR is defined as the linear speed of the rotor to the wind speed (Ahmed et al ., 2009).

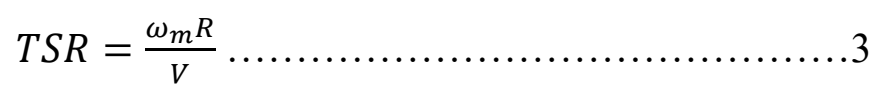

where $\mathrm{R}$ and $\omega_{m}$ are the turbine radius and the angular speed, respectively. In practical designs, the maximum achievable $\mathrm{Cp}$ ranges between 0.4 to 0.5 for modern high-speed turbines and between 0.2 to 0.4 for slow-speed turbines. Attaining $\mathrm{Cp}$ above 0.4 is considered good. Whatever maximum value is attainable with a given wind turbine, it must be maintained constantly at that value for the efficient capture of maximum wind power. A relatively small deviation on either side of the TSR will result in a significant reduction of the power available for conversion to electrical energy.

A Generic $3 \mathrm{~kW}$ wind turbine with a hub height of 50 meters was also selected for the hybrid system for Adem Tuleman due to the low cut-in wind speed and high performance for low wind speed in the place. The maximum life span of the turbine is 25 years for iteration purposes the size variation ranging from 0 up to 12 is considered.

\subsubsection{Diesel Generator}

A diesel generator in a renewable hybrid system often eliminates the need to build in system autonomy and adds to the system's reliability. Also, the design capacity of the hybrid system component can often be reduced as compared with their required sizing in single-source systems. Diesel generator system design simply involves selecting a locally available unit that is closest to the peak load required for the village. For the hybrid standalone power system, the diesel generator is used as a backup energy source when solar and wind energy are not sufficient to provide the required power output. 


\subsubsection{Energy storage (Battery)}

Sizing of the battery begins by determining the estimated energy storage ( $\left.\mathrm{E}_{\text {storage }}\right)$, which can be calculated as follow:-

$$
E_{\text {storage }}=E_{\text {demand }} * D_{\text {aut }} \ldots \ldots \ldots \ldots \ldots \ldots \ldots \ldots \ldots \ldots
$$

The amount of energy storage $\mathrm{E}_{\text {storage }}$ is the multiplication of village energy demand and the number of autonomy days $\left(\mathrm{D}_{\text {aut }}\right)$. For safety purposes, the result obtained is divided by the maximum allowable level of discharge (MDOD).

$$
E_{\text {safe }}=\frac{\text { energy storage required }}{\text { depth of discharge }} \ldots \ldots \ldots \ldots \ldots \ldots \ldots \ldots
$$

\subsubsection{Inverter Size}

The major function of a converter in a hybrid system is to convert DC power generated by PV, wind, and the backup battery to the AC supply (Ashour, 2019). During inverter sizing, the actual power of the village drawn from the appliances that will run at the same time must be determined as a first step.

\subsection{Hybrid Energy System Design}

A hybrid energy system is the engineering design of hybridizing power supply components or pairing them, for this case study solar and wind energy is rearranged in parallel to provide power and diesel generator which would be used as a back energy source when the power generated by solar and wind turbine is not sufficient. So, a Hybrid energy system is a technical approach to integrating diverse energy sources, energy storage, and energy management. Through this case study, complete energy system analyses were carried out which include detailed energy demands and renewable energy potential of Adem Tuleman as described in Table 2 and Table 4 respectively. 


\subsection{Optimization Standalone Hybrid Energy System}

Optimization of hybrid energy systems involves finding the cheapest combination of all hybrid systems (wind, solar, and diesel generator as backup) and storage capacity that will meet the anticipated demand load with a minimum acceptable level of security (Bhandari et al., 2015; Ashok, 2007). Several design criteria based on economic, reliability, load, etc. have been adopted for optimal designing of the hybrid energy system for Adem Tuleman village. HOMER software that can perform three principal tasks namely simulation, optimization, and sensitivity analysis was used for system optimization.

The analysis has been carried out by considering the other vital key factors, such as lowest NPC, cost of energy (COE), and renewable fraction to evaluate the optimum system model in the mentioned region to meet the desired load. After simulating the NPC value, COE and renewable penetration for all models are presented in section 3.1.

\section{Results and Discussion}

\subsection{HOMER Optimization Result}

The HOMER software repeat iterations to obtain the optimal result in every selection sensitivity variable for the hybrid renewable energy system (Kumar et al., 2016). In this analysis, HOMER provides micro-optimization models of a standalone hybrid energy system based on different design parameters such as initial investment, NPC, COE, consumption of energy/fuel, and environmental sustainability. By varying those factors HOMER software generate different system combinations of power sources as shown in figure 8 and figure 9. 


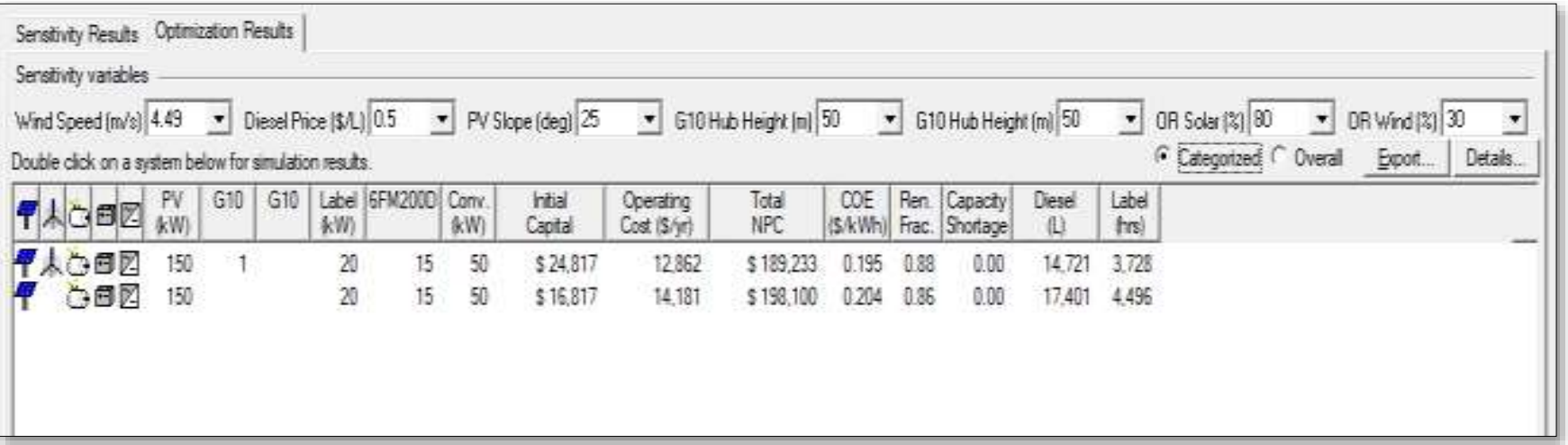

Figure 8 The Cheapest Combination of the hybrid system obtained by HOMER

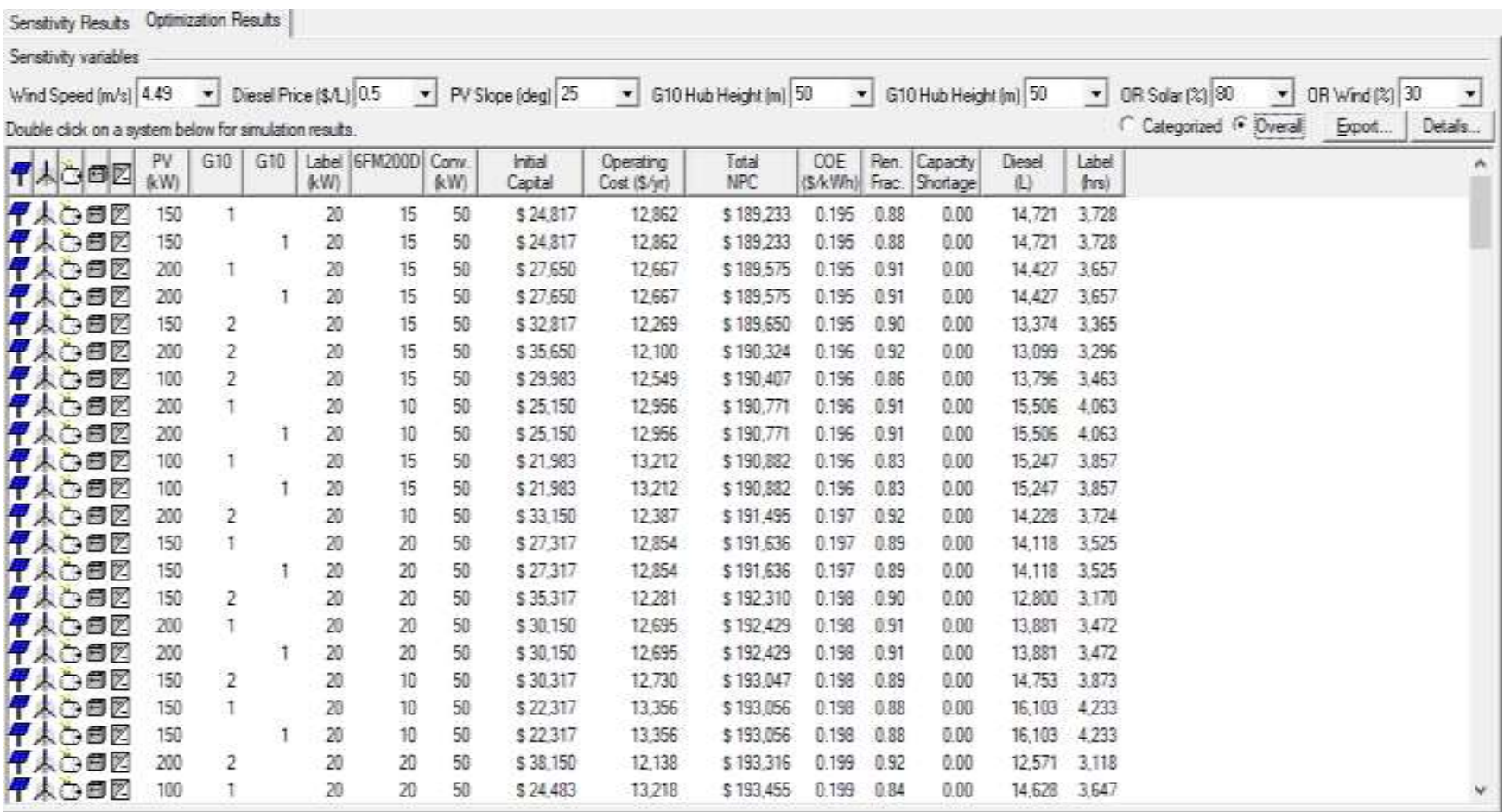

Figure 9 Overall system simulation obtained by HOMER.

From figure 8 the two possible combinations of standalone hybrid systems which give the optimal design of the system to electrify the village. The recommended hybrid standalone energy system has estimated initial cost, operating and maintenance cost, and NPC of $\$ 24,817.00, \$ 12,862.00$, and $\$ 189,233.00$ respectively, with the corresponding cost of energy $\$ 0.195 / \mathrm{kWh}$ from Table 5. The cost of energy obtain here is before any subsidy from the government. The cost of energy obtained during this study is relatively higher than the current energy tariff in Ethiopia that is due to the fuel cost of the diesel generator. From 
Figure 10, it is clearly visible that fuel cost incur large amount of investment during the project life time. This can be managed by using a battery to store excess energy of renewable energy produced which minimizes the running time of generators.

Table 5 Net Present Costs of PV/Wind/Diesel/Battery Hybrid System

\begin{tabular}{lllllll}
\hline $\begin{array}{l}\text { System } \\
\text { components }\end{array}$ & Capital $(\$)$ & $\begin{array}{l}\text { Replacement } \\
(\$)\end{array}$ & O \& M (\$) & Fuel $(\$)$ & Salvage $(\$)$ & $\begin{array}{l}\text { Total NPC } \\
(\$)\end{array}$ \\
\hline PV & $8,500.00$ & $2,650.00$ & 128.00 & 0.00 & $-1,485.00$ & $9,783.00$ \\
$\begin{array}{l}\text { Generic10kW, } \\
\text { wind turbine }\end{array}$ & $8,000.00$ & $3,338.00$ & $1,918.00$ & 0.00 & -621.00 & $12,634.00$ \\
$\begin{array}{l}\text { Generator } \\
\text { Converter }\end{array}$ & 367.00 & $1,048.00$ & $31,771.00$ & $94,089.00$ & -67.00 & $127,208.00$ \\
$\begin{array}{l}\text { Batteries } \\
\text { System }\end{array}$ & 750.00 & 188.00 & 128.00 & 0.00 & -35 & 731.00 \\
\hline
\end{tabular}

According to information from the Ethiopian Electric Utility (EEU), the existing electric power generation, transmission, and distribution costs are categorized by block range as shown in Table 6. Based on these standards, the Energy demand of Adem Tuleman is categorized under the $4^{\text {th }}$ block in which the base energy tariff is $0.55 \mathrm{birr} / \mathrm{kWh}(\$ 0.014 \mathrm{kWh})$ and increased up to 2 birr/kWh $(\$ 0.051)$ (Tigabu, 2018). The result obtained through this study is more expensive than the current electric tariff in Ethiopia, which is due to fuel cost and can be managed by switching to renewable energy only.

Table 6 Energy Tariff for Residential Consumer Category, in Ethiopia

\begin{tabular}{lllllll}
\hline S/N & Block Range & Base Tariff in & \multicolumn{5}{l}{ Energy } & Tariff (Birr/kWh) & \\
& & ETB (birr) & Dec-18 & Dec-19 & Dec-20 & Dec-21 \\
\hline 1 & $1^{\text {st }}$ block up to 50kWh & 0.273 & 0.273 & 0.273 & 0.273 & 0.273 \\
2 & $2^{\text {nd }}$ block Up to100kWh & 0.3564 & 0.4591 & 0.5617 & 0.6644 & 0.767 \\
3 & $3^{\text {rd }}$ block up to 200kWh & 0.4993 & 0.7807 & 1.0622 & 1.3436 & 1.625 \\
4 & $4^{\text {th }}$ block up to 300kWh & 0.550 & 0.9125 & 1.2750 & 1.6375 & 2.000 \\
5 & $5^{\text {th }}$ block up to 400kWh & 0.5666 & 0.9750 & 1.3833 & 1.7917 & 2.200 \\
6 & $6^{\text {th }}$ block up to 500kWh & 0.5880 & 1.0423 & 1.4965 & 1.9508 & 2.4050 \\
7 & $7^{\text {th }}$ block >500kWh & 0.6943 & 1.1410 & 1.5877 & 2.0343 & 2.4810 \\
8 & Service charge post-paid 0-50kWH ETB 10.00; Beyond 50KWH ETB42.00 & \\
\hline \multicolumn{5}{l}{ Source: - (Tigabu, 2018) }
\end{tabular}


Regardless of the cost of energy, still, the proposed project has a lot of advantages over the national grid in the area were at a lengthy distance from the grid, dispersed population, and low energy demands, yet the village would favour off-grid electrification. Besides, the standalone hybrid system will decrease the cost of energy production, transmission line, distribution, and environmental benefit. Moreover, hybrid energy systems allow the effective way of utilizing available renewable energy in the village and providing clean energy which can alleviate energy poverty in many remote sites of Ethiopia.

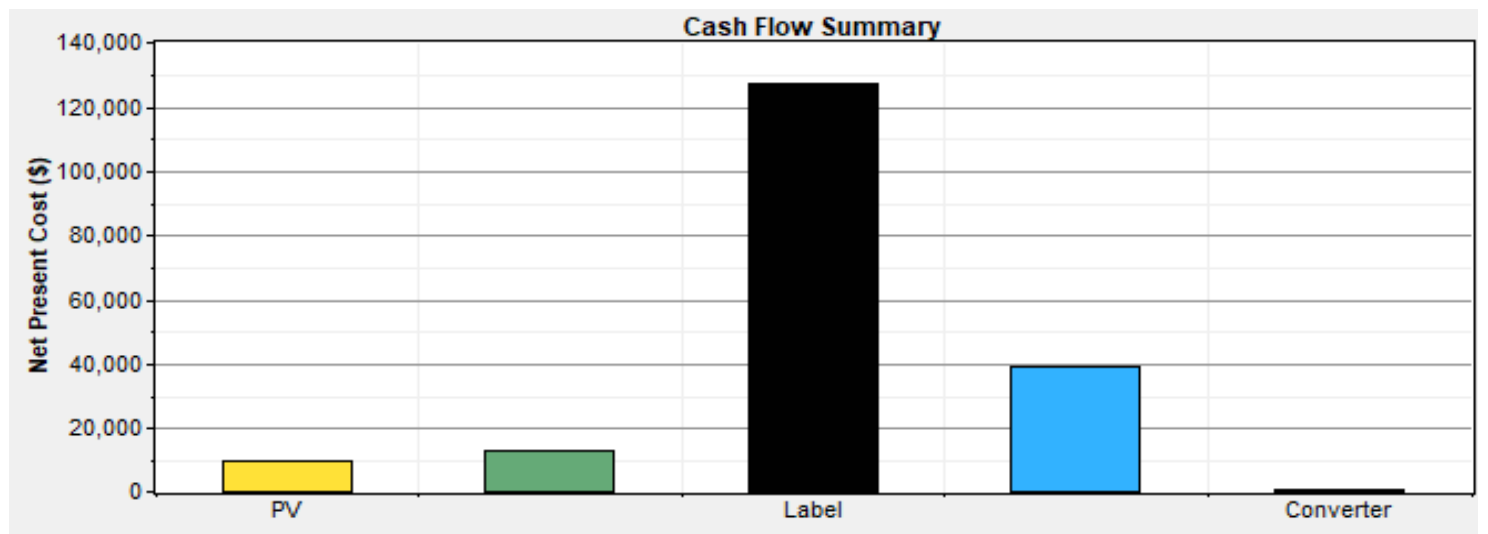

Figure 10. Project lifetime cash flow summaries

The proposed project's econometric variables such as internal rate of return, the rate of investment, and the payback period are important to decide for the optimal configuration of the hybrid energy system for the village. Owing to HOMER software results, the designed hybrid energy system has a $14 \%$ of internal rate of return and $12 \%$ rate of investment, with five years of payback initial investment.

The yearly electricity production and consumption information can be observed in Table 7 and Figure 11. It shows that the PV system generates the major portion of the total electricity, followed by a diesel generator and wind turbine. The purpose of a diesel generator and battery system is to support the excess load. Thus the production of the wind turbine is low due to the available average wind speed of the site under this study. From Table 7, it is clear that there is excess electricity production of $376,166 \mathrm{kWh} / \mathrm{year}$. Most of this amount is 
generated by PV or Wind due to their environment dependence, which can be reduced by load shifting. As this hybrid system has a diesel generator, it will certainly emit exhaust gas. HOMER estimated the possible emission amount at the provided operation strategy. Hence, the pollutant gas emissions rates were $38,764 \mathrm{~kg} / \mathrm{yr} ., 854.00 \mathrm{~kg} / \mathrm{yr}$., and $95.70 \mathrm{~kg} / \mathrm{yr}$. of carbon dioxide, nitrogen oxide and carbon monoxide respectively. The emission due to generator can manageable by storing excess power produced by solar panel and wind turbine.

Table 7 Annual Electric Energy Productions and Consumption of the Hybrid System

\begin{tabular}{llllll}
\hline \multicolumn{1}{c}{ Production (kWh/yr.) } & \multicolumn{2}{c}{$\%$} & \multicolumn{2}{c}{ Consumption $(\mathrm{kWh} / \mathrm{yr})}$. & \multicolumn{1}{c}{$\%$} \\
\hline PV array & $249,388.00$ & 83 & AC primary load & $74,460.00$ & 98 \\
Wind turbine & $15,652.00$ & 5 & Deferrable load & $1,642.00$ & 2 \\
Generator 1 & $35,024.00$ & 12 & Total & $76,103.00$ & 100 \\
Total & $300,064.00$ & 100 & & & \\
\hline
\end{tabular}

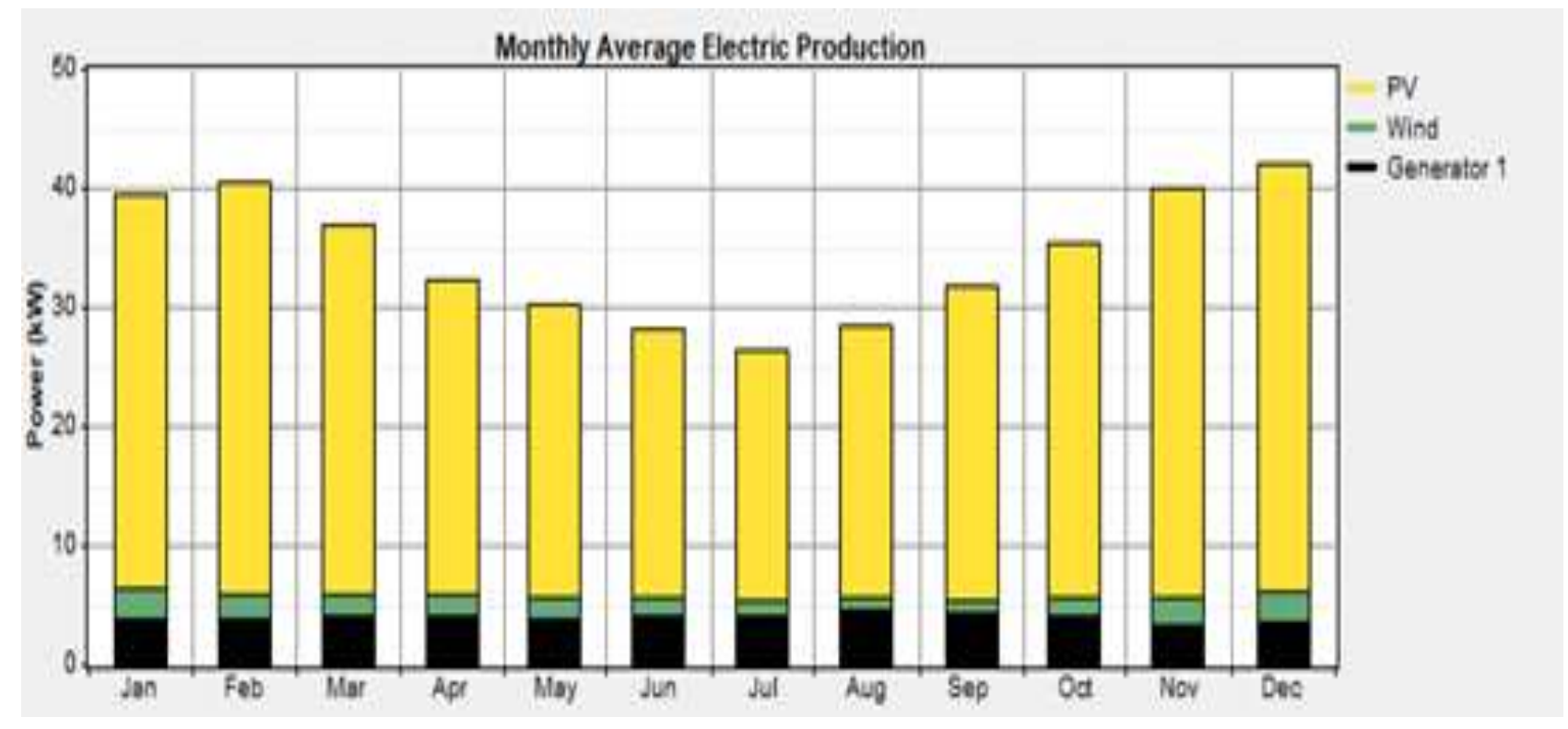

Figure 11 Monthly average electric production of hybrid system

As shown in Figure 11, PV generates more electricity compared to other components in the system (wind and diesel generator). Consequently, this paper gives a good incitation about the site energy resource potential and provides the suggestion for government or non- 
governmental organization to solve lack of electric access which is the critical problem of the village.

\subsection{Comparison of Current Energy Source versus Designed Hybrid Energy}

\subsubsection{Current Energy Source of Adem Tuleman}

Plant biomass fuel is a major source of energy supply in eastern Africa. In Ethiopia, it contributes over $95 \%$ of the country's total energy, of which woody biomass caters for $82 \%$ (KASSAHUN BEKELE et al, 2013). However, the heavy reliance on biomass energy has become a threat to forest ecosystems and a major cause of land resource degradation. As fuelwood becomes scarce, rural households are left with no alternative source of energy, other than depending on locally available resources such as crop residues and cattle manure. Besides, the threat to forest and land degradation, the noxious and hazardous products of biomass combustion, particularly indoor smoke, in poorly ventilated houses, are a major source of health problems including acute and chronic respiratory diseases, eye diseases, low birth weights, and increased infant mortality.

High biomass energy consumption along with inefficient utilization has contributed for; removes the wood energy resource, deforestation, biodiversity loss, land degradation, desertification, reduced water quality, increase in sedimentation, dust storms occurrence, and air pollution. In addition, reliance on biomass fuels for cooking livelihood has several negative implications such as indoor air pollution, which lead to serious respiratory disease especially for female, collecting firewood is time-consuming, this affect quality of education period particularly women and children, and excess biomass combustion release GHS emission (Jung and Huxham, 2018; Mazzoni and Isaac, 2003).

Therefore, to reduce unsustainable way of biomass energy utilization and its health impact shifting from traditional energy use to clean energy technology is mandatory. Besides shifting 
to clean energy sources, improving the efficiency of the cooking stove is the permissible solution in saving biomass energy. Biomass cooking stoves are mainly found in developing countries like Ethiopia and represent basic ways of cooking food. Cooking on traditional biomass stoves is mostly related to very low levels of energy efficiency. The common type of cooking with biomass is the so-called "three-stone fire", which is made by arranging three stones in such a way that it is possible to place a pot for cooking above it. Although this type of biomass cooking is most inefficient and bears serious risks to human health and the environment, it has been around for thousands of years and still the most prevalent way of cooking in the world (Asres, 2012).

In general, a hybrid standalone energy system is an economical approach for rural electrification with a lot of socio-economic benefits and environmental advantages over traditional biomass energy.

\subsubsection{Off-grid hybrid energy system versus Grid extension for Disperse Population}

Energy access is the golden thread that joins three sustainability dimensions, economic prosperity, social development, and living the environmental limits (Bhattacharyya and Palit,

2019). A combination of energy solutions is required to bridge the gap optimally. Such combinations could involve the use of both renewable and non-renewable sources of energy through grid extensions and the development of local off-grid solutions.

Many rural communities are characterized by a low population density and less intensive energy demand. As it shown in Table 2 section 2.3, Adem Tuleman kebele's energy demands basically for lighting, TV, health center; school, church, and water pump which is usually limited to less than $300 \mathrm{~kW}$ energy per day. The dispersed population, the distance from the grid line, and low energy consumption are the major factors that make grid extension for the village more expensive as well as insufficient power generation capacity which can even not 
secure energy demands of the urban and pre-urban communities in Ethiopia is another challenge in the country to power rural village. Therefore, an off-grid hybrid energy system supply is one way of rural electrification with local energy generation and distribution.

\subsubsection{Benefit and Implementation of Hybrid Energy System for Remote Area}

Hybrid systems are a combination of two or more different but complementary energy supply systems located in a remote site (Bhattacharyya and Palit, 2016). Hybrid energy systems play a vital role in changing the lifestyle of communities in remote areas and have a dozen packages of socioeconomic, energy security, and environmental benefits. Here are the shortlisted benefits gained from off-grid hybrid energy system:-decrease environmental pollution, extend access to electricity, energy-saving (reduces the purchase of fossil fuels), abatement of global warming $\left(\mathrm{CO}_{2}\right.$ and other greenhouse gases are minimized), socioeconomic development (develops employment opportunities in rural areas, diversity of energy carriers and suppliers, and decentralization of power generation (reduces the requirement for transmission lines within the electricity grid (Mondal and Ringler, 2020).

The advantage of hybrid systems is their ability to avoid fluctuations in the system's energy supply, which is the main disadvantage of stand-alone renewable energy technologies such as wind, PV, and diesel generators as a backup source of energy. A hybrid system will provide a relatively constant delivery of energy even when one of the supply devices of the system is unable to generate power (lack of wind in the case of a windmill or sunlight in the case of a PV. Often, hybrid systems will be a combination of different renewable energy technologies, sometimes coupled with diesel generators. Typical hybrid systems are photovoltaic/wind systems, wind/diesel systems, wind/photovoltaic/micro hydropower systems, or wind/small hydropower, and so forth. 
In this case study, the solar, wind, and diesel generator are combined to supply the energy demands of Adem Tuleman. The choice of specific energy technology for rural electrification of rural or remote areas usually depends on the available source of energy, energy demands of the village, and the primary load of the village.

\section{CONCLUSION}

This paper has presents the feasibility of the hybrid energy model design and optimization of a standalone hybrid system using homer software for a remote area of Ethiopia. The load is assumed based on the regular rural lifestyle in the country and previous studies. The main parameters of analysis are per unit energy cost, initial cost, per year operating cost, and total net present cost of the system. The HOMER optimization is capable to clarify the viability of the system since the system has competitive energy costs with other possible configurations. The system is a non-polluting, reliable energy source with the initial, operating, and maintenance cost, and totals NPC of $\$ 24,817.00, \$ 12,862.00$, and $\$ 189,233.00$ respectively. The cost of energy is $\$ 0.195 / \mathrm{kWh}$ which is the lowest of the entire possible system configuration generated by using HOMER software. As reveals from the results, the cost of energy seems expensive or not in line with the current tariff of energy in Ethiopia. However, considering the impossibility of the grid connection, its environmental advantage, dispersed population, and low energy demands in the village, in consideration of some incentives it could be implemented. In addition, from the investment payback period, we can conclude that the cost of energy can be minimized to an affordable price to support the lower-class family in the village without affecting project revenue since the project lifetime is 25 years.

The study shows that the proposed system is more reliable and cost-effective and also more environmentally friendly when compared with the kerosene-based and traditional biomass combustion for daily livelihood which is the main source of energy. The transformation to 
clean energy hopefully convey better economic opportunities and productivities, thereby, improving rural communities overall welfare. In order for this happen on the ground the government must improve and fast track the application process. For instant, giving priority for renewable energy power generation particularly off-grid, Inviting private sector and providing financial incentive for renewable energy based power generation (i.e. tax rebates, renewable energy incentive as percentage of the amount of renewable energy supplied).

In General, through this investigation off grid hybrid energy system is feasible and reliable approach in electrifying remote area of developing countries like Ethiopia. Hence, hybrid energy system plays significant role in securing growing energy demands and alleviating energy poverty of remote village.

\section{Acknowledgements}

The Authors would like to thanks all individual and governmental office those assist the researchers during data collection and providing useful information about daily energy demand of the village, population size.

\section{Ethics approval and consent to participate}

Not Applicable

\section{Consent for publication}

Not Applicable

\section{Availability of supporting data}

Not Applicable

\section{Competing interests}

No competing interests

\section{Funding}

No Fund

\section{Authors' contributions}

Not Applicable 


\section{Reference}

Ahmed, N. A., Miyatake, M. and Al-Othman, A. K. (2009) 'Hybrid solar photovoltaic/wind turbine energy generation system with voltage-based maximum power point tracking', Electric Power Components and Systems, 37(1), pp. 43-60. doi: 10.1080/15325000802322012.

Ani, V. A. (2016) 'Design of a Reliable Hybrid (PV/Diesel) Power System with Energy Storage in Batteries for Remote Residential Home', Journal of Energy, 2016, pp. 1-16. doi: 10.1155/2016/6278138.

Ashok, S. (2007) 'Optimised model for community-based hybrid energy system', Renewable Energy, 32(7), pp. 1155-1164. doi:

10.1016/j.renene.2006.04.008.

Ashour, A. (2019) 'Solar Inverter for Home Working of Solar Inverter ':, (December).

Asres, T. S. (2012) 'The Current Status of Traditional Biomass Energy Utilization and Its Alternative Renewable Energy Technology in the Amhara Region of Ethiopia', p. 104.

Bekere, Y. B. and Megerssa, G. R. (2020) 'Role of biogas technology adoption 
in forest conservations: Evidence from Ethiopia', Journal of Degraded and Mining Lands Management, 7(2), pp. 2035-2039. doi:

10.15243/jdmlm.2020.072.2035.

Bhandari, B. et al. (2015) 'Optimization of hybrid renewable energy power systems: A review', International Journal of Precision Engineering and Manufacturing - Green Technology, 2(1), pp. 99-112. doi: 10.1007/s40684015-0013-z.

Bhattacharyya, S. C. and Palit, D. (2016) 'Mini-grid based off-grid electri fi cation to enhance electricity access in developing countries : What policies may be required ?', Energy Policy, 94, pp. 166-178. doi:

10.1016/j.enpol.2016.04.010.

Bhattacharyya, S. C. and Palit, D. (2019) 'The nexus of grids, mini-grids and off-grid options for expanding electricity access', Oxford Policy Management, (February 2020), pp. 1-42. Available at:

https://energyeconomicgrowth.org/publication/nexus-grids-mini-grids-and-gridoptions-expanding-electricity-access.

Boait, P. J. (2014) 'Technical Aspects of Mini-Grids for Rural Electrification', in Green Energy and Technology, pp. 37-61. doi: 10.1007/978-3-319-04816$1 \_3$. 
Chang, K. H. and Lin, G. (2015) 'Optimal design of hybrid renewable energy systems using simulation optimization', Simulation Modelling Practice and Theory, 52, pp. 40-51. doi: 10.1016/j.simpat.2014.12.002.

Davis, R. and Watts, P. (no date) ‘4. Water requirements Drinking Water Feed Processing Cattle Washing Administration Sundry QDPI 24ML/1000 Head-onFeed FEEDLOT DESIGN AND CONSTRUCTION 2 FEEDLOT DESIGN AND CONSTRUCTION 4. Water requirements'. Available at: https://www.mla.com.au/globalassets/mla-corporate/research-anddevelopment/program-areas/feeding-finishing-and-nutrition/feedlot-designmanual/04-water-requirements-2016_04_01.pdf.

Derbew, D. (2013) 'Ethiopia’s Renewable Energy Power Potential and Development Opportunities. Ministry of Water and Energy', (June 22, 2013), p. 33.

Dingeto Hailu, A. and Kalbessa Kumsa, D. (2021) 'Ethiopia renewable energy potentials and current state', AIMS Energy, 9(1), pp. 1-14. doi: 10.3934/energy.2021001.

Girma, Z. (2013) 'Hybrid renewable energy design for rural electrification in Ethiopia', Journal of Energy Technologies and Policy, 3(13), pp. 38-53. Available at: 
http://www.iiste.org/Journals/index.php/JETP/article/viewFile/9765/9972.

Girma, Z. (2016) 'Techno-Economic Feasibility of Small Scale Hydropower in Ethiopia: The Case of the Kulfo River, in Southern Ethiopia', Journal of Renewable Energy, 2016, pp. 1-12. doi: 10.1155/2016/8037892.

I.O, Adewumi and B.A, A. (2015) 'Hybrid Solar Power System: Campus Model Solution', 1(11), pp. 447-452. Available at: www.allresearchjournal.com.

Jung, J. and Huxham, M. (2018) 'Firewood usage and indoor air pollution from traditional cooking fires in Gazi Bay, Kenya', Bioscience Horizons, 11, pp. 112. doi: 10.1093/biohorizons/hzy014.

Kang, D. (2020) 'Renewable Energy Options for a Rural Village in North Korea', (2012).

KASSAHUN BEKELE et al (2013) 'Woody and non-woody biomass utilisation for fuel and implications on plant nutrients availability in the mukehantuta watershed in Ethiopia', 21(1), pp. 625-636. doi: 10.4314/acsj.v21i1.

Kumar, P. et al. (2016) 'Optimal Design Configuration Using HOMER', Procedia Technology, 24, pp. 499-504. doi: 10.1016/j.protcy.2016.05.085. 
Martínez, M. and Mart, M. (2017) ‘Stand-alone Hybrid Renewable Energy Systems ( HRES )', PhD Thesis.

Mohanty, P. et al. (2015) PV System Design for Off-Grid Applications PV System Design for Off-Grid Applications. doi: 10.1007/978-3-319-14663-8.

Mohanty, P., Muneer, T. and Gago, E. J. (2016) Solar Photovoltaic System Applications, Solar Photovoltaic System Applications. doi: 10.1007/978-3-31914663-8.

Mondal, M. A. H. et al. (2018a) 'Ethiopian energy status and demand scenarios: Prospects to improve energy efficiency and mitigate GHG emissions', Energy, 149(December), pp. 161-172. doi: 10.1016/j.energy.2018.02.067.

Mondal, M. A. H. et al. (2018b) 'Ethiopian energy status and demand scenarios: Prospects to improve energy efficiency and mitigate GHG emissions', Energy, 149, pp. 161-172. doi: 10.1016/j.energy.2018.02.067.

Mondal, M. A. H. and Ringler, C. (2020) 'Long-term optimization of regional power sector development: Potential for cooperation in the Eastern Nile region?', Energy, 201, p. 117703. doi: 10.1016/j.energy.2020.117703.

Muda, W. M. W. and Fong, C. A. (2014) 'Simulation-based method to evaluate 
a PV/wind hybrid renewable energy system in Terengganu', WIT Transactions on Ecology and the Environment, 186, pp. 91-102. doi: 10.2495/ESUS140081.

Negash, D. et al. (2017) 'Household energy and recycling of nutrients and carbon to the soil in integrated crop-livestock farming systems: a case study in Kumbursa village, Central Highlands of Ethiopia’, GCB Bioenergy, 9(10), pp. 1588-1601. doi: 10.1111/gcbb.12459.

O. Mazzoni and H. Isaac (2003) 'Fuel Substitution Impacts: an Assessment Matrix Analysis', pp. 1-15. Available at:

https://assets.publishing.service.gov.uk/media/57a08d1740f0b6497400163c/R8 019Annex5.pdf.

Pumps, G. (2000) 'Pump Selection Guide’, Pumps, pp. 1-82. Available at: https://brownbros.com.au/files/Brochures/BROCHURE_Xylem__Pump_Selection_Guide__0412.pdf.

Sawle, Y., Gupta, S. C. and Bohre, A. K. (2018) 'Review of hybrid renewable energy systems with comparative analysis of off-grid hybrid system', Renewable and Sustainable Energy Reviews, 81(May), pp. 2217-2235. doi: 10.1016/j.rser.2017.06.033.

Sharma, S. K. and Bereket, B. W. (2008) 'Water supply systems in selected 
urban poor areas of Addis Ababa, Ethiopia', Access to Sanitation and Safe Water: Global Partnerships and Local Actions - Proceedings of the 33rd WEDC International Conference, (i), pp. 431-434.

Tajebe, L. (2016) 'Bio-Gas Technology Adoption in Rural Ethiopia : It' s Effect on the Crisis of Deforestation', 6(1), pp. 1-8.

Tessama, Z. et al. (2013) 'Mainstreaming Sustainable Energy Access into National Development Planning: the Case of Ethiopia', Stockholm Environment Institute, Working Papaer, (February). doi: 10.13140/2.1.3430.2401.

Tigabu Atalo (2018) ‘Ethiopian Energy Power Business Portal, EepBp’, pp. 15. Available at: https://www.ethioenergybuz.com/en/.

Udayakanthi, M. V. P. G. (2015) 'Design of a Wind-Solar Hybrid Power Generation System in Sri Lanka', pp. 1-59. doi: 10.1016/j.jmmm.2007.01.005.

Vázquez, F. I. et al. (2012) 'Demand side management for stand-alone hybrid power systems based on load identification', Energies, 5(11), pp. 4517-4532. doi: 10.3390/en5114517.

Woldeamanuel, A. A. (2017) 'Determinants of Household Energy Consumption in Urban Areas of Determinants of Household Energy Consumption in Urban 
Areas of Ethiopia', (November 2017), pp. 0-12.

World Bank (2017) 'Federal Democratic Republic of Ethiopia Country

Environmental Analysis ( CEA ): Ethiopia Realizing Green Transformation', p.

133. 